\title{
Parents' and English Language Teachers' Views about Early Foreign Language Education in Turkey
}

\author{
Dilek ÇAKICI* \\ English Language Teaching Department, Ondokuz Mayls University, Samsun, Turkey
}

\begin{abstract}
With the technological developments, social, cultural and political relations among countries have increased nowadays, and this has increased the interaction among people. Therefore, countries which want to get knowledge about different countries; to understand them and to improve their relations with them has begun to place much more emphasis on foreign language education. Turkey, which is a candidate country for EU membership, has gradually decreased the starting age of foreign language learning. Firstly, it was decreased at the 4th grade of primary schools, and recently it has decreased at the 2 nd grade classes. This study aims to give some information about the history of early foreign language teaching both in the world and Turkey, and to describe the views of parents and English language teachers of primary school students about the optimal age for foreign language learning and early foreign language education after the recent regulation change in Turkey. It is expected that the views of the English language teachers may provide some information especially about the deficiencies in early foreign language education, and that the views of the parents may show what the parents' attitudes and views about early foreign language learning in Turkey are. A total of 205 EFL primary school teachers and 212 parents voluntarily participated in the study. Two different questionnaires have been used to collect data for the research. In the light of the questionnaires, it is concluded that teachers and parents attending the research are in favor of early foreign language education, especially at between the ages 4-7. It shows that the recent regulation change, which states English courses will be started at the 2 nd grade of the primary schools, is a positive and valuable attempt for early foreign language education in Turkey.
\end{abstract}

Keywords: foreign language; foreign language teaching; early foreign language education

\section{Introduction}

Thanks to the technological developments, people are able to reach every people around the world, get knowledge about the events in the world easily, and they expose foreign languages much more than ever via TV, games, social networks etc. This makes foreign language teaching and learning inevitable for us. According to Mauranen and Ranta (2009, p.1), English language has been inarguably accepted as the lingua franca, and also it has become one of the symbols of our time, like globalization, economic integration, networking, and the Internet. Therefore, English as a foreign and second language has gained much more

\footnotetext{
*dcakici@omu.edu.tr
} 
importance than ever. For instance, all of the students in 14 members of Europe or within the regions of these countries must learn English language, and generally it is the first foreign language they have to learn. Moreover, English language is the most widely taught foreign language in all of the educational systems of Europe except the Flemish Community of Belgium and Luxembourg, and this has increasingly become the case over the last few years (Eurydice, 2012).

As Genç İlter and Er state (2007), "the starting age of learning a foreign language has decreased to 5-6 years old nowadays since the world has turned into a small village and the interaction among people has increased" (p.21). Recently, the countries which have realized the significance of foreign language education have followed certain policy making approaches in order to be able to conduct foreign language education well. Starting of foreign language education at an early age is one of these policies (Küçüktepe, Eminoğlu Küçüktepe and Baykın, 2014). Turkey which aims to be a member of the European Union, and which has been trying to understand, adopt and use the technology and science of the era has taken some steps for early foreign language education. As a result of some recent educational regulations in Turkey, the starting age of learning English as a foreign language has been decreased to 2nd grade students, and also a new English language curriculum was developed accordingly. According to Turkish Education Board of Ministry of National Education decision dated 25.06.2012 and numbered 69 about "Weekly Course Schedule of Primary Educational Institutions (primary and secondary schools)", it has been decided that foreign language education, which started at 4th grade of primary schools, will start at 2nd grade (MEB, 2012).

Different cultures make similar points about the difficulty of teaching new things to adults compared to children. It is a known fact that age factor has great importance in the first language acquisition and second language acquisition and learning. Demirezen (2003) states that during language learning process, it does not matter it is first or second language learning, there are some critical periods depending on age that can be proved concretely, and that should be taken into consideration seriously. According to him, if these periods could not be handled effectively by family, school and environment, significant problems would emerge both in L1 and L2 education. In this respect, viewpoints of parents and English language teachers who are active in this process are so valuable in order to see the advantages, disadvantages, and shortcomings of early foreign language education in Turkey. With the help of these views, more concrete and accurate findings can be reached, and it may shed light on the prospective studies in order to improve foreign language policies in Turkey.

\section{The critical period hypothesis $(\mathrm{CPH})$ in learning an additional language}

Experts agree that there is a "critical period" for acquiring a first language, in that if this has not occurred by roughly the onset of puberty, it is highly unlikely to occur. There has however been extensive debate concerning the existence and possible scope of a critical period for subsequent languages. There is little doubt that in society at large many people intuitively that young children possess some inherent advantage in learning languages, and so there is a widespread view that "the younger, the better. Penfield was the first to claim that there is a critical period for language acquisition. Lenneberg maintained Penfield's line of thought. Lenneberg's hypothesis is that language can be acquired only within a critical period which extends from early infancy until puberty (Johnson and Newport, 1989, p.60). As Birdsong (1999) claims, "once this window of opportunity for language acquisition is passed, however, the ability to learn language declines" (p.1). Lenneberg's hypothesis concerned only first language acquisition; however he left open the question of whether this critical period

Participatory Educational Research (PER) 
extended to second language acquisition (Johnson and Newport, 1989, p.60). A number of important reviews of the research literature on $\mathrm{CPH}$ and second languages have been published. Scovel's (2000) review indicates that during the 1980s expert opinion swung away from the $\mathrm{CPH}$.

Researchers are still having different opinions about the effects of the critical period hypothesis on second language learning. Some researchers claim that once a critical period ends, whether in L1 or L2 learning, native-like proficiency can never be attained. However, other researchers claim that age does not affect second language learning. Nevertheless, many researchers seem to believe that age is closely connected with second language acquisition (Takutome, 2010). Age has often been considered as one of the major factors determining success in learning a second or foreign language. Children are generally considered capable of acquiring a new language rapidly and with little effort, while adults are believed to be condemned to failure (Marinova-Todd, Marshall, and Snow, 2000, p. 9).

Furthermore, Salthouse states along with social factors, there are age-related changes in cognitive processing affecting the ability to learn a new language. Therefore, older learners would have more difficulties in acquiring a second language (as cited in Gül, 2009). In the light of the information above, it is reasonable to say that the age factor is vital for foreign language education.

\section{Historical background of early foreign language education in the world}

The history of foreign language teaching at an early age in educational institutions does not date back to a long time. As O'Neil states, with the FLES (Foreign Languages in Elementary Schools) movement in the USA, trials for early foreign language education began in Eastern European countries and in the Soviet Union after 1920. It gained importance with the establishment of "modern language association" in 1950 after the World War II. In 1950s, pilot implementations started with the project named "English witaut a book" in Sweden, and then some pilot implementations were applied in France and England within the scope of similar projects (as cited in Aslan, 2008).

The first big step for early foreign language education in primary schools was taken in 1960s. A strong consensus was reached for early foreign language education in numerous conferences including UNESCO conferences in 1962 and 1966. Switzerland (1962), Norway (1969), Finland and Germany (1970), Austria (1983), Netherlands (1985) and France (1992) were among the European countries which began early foreign language education in primary schools. Thanks to abovementioned developments, attempts for early foreign language education in primary schools, which was densely seen in 1970s, have been put into practice since the late of 1980s and early 1990s in most of the members of European Union (Yildiran and Tanriseven, 2015, p. 211).

\section{Early foreign language education in Turkey}

Foreign language education in our country started in the secondary schools during the Ottoman Empire in the late of 19th century. Until the establishment of the Turkish Republic, it continued to be taught generally in foreign and private schools. In the republican period, it entered into the curriculum of national secondary and higher education. At first, French, German and English languages were taught in parallel with the international relations of Turkey. However, English language has come into prominence almost in all of the schools since 1980s (Aküzel, 2006, p.9). 
The most crucial step for early foreign language education in Turkey was taken in 1997-1998 school years. As a result of "Eight Years Mandatory Education Reform", mandatory education increased 8 years, and foreign language education, which was started at 6th grade, was decided to be started at 4th grade of primary school (Yildiran and Tanriseven, 2015). According to Demirezen (2003), it was an enormous scientific regulation made in the light of findings of biolinguistics and neurolinguistics about the critical periods for foreign language learning. More appropriate environment was created for foreign language learning.

Recently, very significant improvement has taken place in Turkey. The age of learning English as a foreign language was decreased, and also a new English language curriculum was developed accordingly. According to Ministry of National Education Turkish Education Board's decision, it has been decided that foreign language education, which started at 4th grade, will start at 2 nd grade. When the average of the starting age of foreign language education in Europe is taken into consideration, it is clearly seen that Turkey has caught the European standards with regard to the starting age for foreign language learning via this regulation change. In the light of critical period hypothesis and the tendency for early foreign language education in the world, it can be said that this regulation is a very important step for Turkey's foreign language education system.

\section{Purpose of the study}

The main purpose of this study is to investigate parents' and English language teachers' views about the optimal age for foreign language education, deficiencies in the early foreign language education in Turkey and their expectations in order to describe the present situation of early foreign language education in our country.

\section{Participants}

A total of 205 EFL primary school teachers and a total of 212 parents voluntarily participated in the study.

\section{Data collection instrument}

In order to investigate the views of English language teachers working at primary schools and parents whose children are studying at primary school about early foreign language education in Turkey, two different questionnaires have been given to parents and English language teachers. The questionnaires developed by Atadere (2012) were revised for this study. The questionnaire for English language teachers consists of 31 questions, while the questionnaire for parents consists of 24 questions. In both of the questionnaires, the questions including checkboxes have been used to see to which of the given situations they feel closer themselves. Data was analyzed using 17.0 SPSS package program. Collected data was analyzed by descriptively (frequencies).

\section{Findings and discussions}

The main purpose of this study is to determine parents' and English language teachers' views about the optimal age for foreign language education, deficiencies in the early foreign language education in Turkey and their expectations in order to describe the present situation of early foreign language education in our country. To this end the views of both parents' and teachers' about optimal age for starting to learn a foreign language are statistically analyzed in the first phase. The related table is given below: 
Tablo 1. Views about the Starting Age for Foreign Language Education

\begin{tabular}{ccc}
\hline Age & Teachers & Parents \\
\hline $0-3$ & $40 \%$ & $20 \%$ \\
\hline $4-7$ & $50 \%$ & $43.3 \%$ \\
\hline $8-11$ & $10 \%$ & $36.7 \%$ \\
\hline $12-15$ & $0 \%$ & $3.3 \%$ \\
\hline 16 and above & $0 \%$ & $0 \%$ \\
\hline
\end{tabular}

According to Table 1, 50\% of the teachers are in favor of the ages 4-7 for early foreign language education. In addition, $40 \%$ of them are in favor of the ages $0-3$. It shows that most of the teachers agree that early foreign language education should start at preschool. As can be seen above, $43.3 \%$ of the parents are in favor of between the ages $4-7$, and between the ages 8-10 follows it. Although they agree with the teachers on 4-7 ages, they separate from each other about the ages 8-11 and 0-3.

Tablo 2. Views about the Advantages of Early Foreign Language Education

\begin{tabular}{lcc}
\hline & Teachers & Parents \\
\hline Children at an early age have more tendency towards language acquisition. & $73.7 \%$ & $40 \%$ \\
\hline Children at an early age have no prejudice against foreign language. & $52.6 \%$ & $16.7 \%$ \\
\hline $\begin{array}{l}\text { Perception of the children at an early age against foreign language is more } \\
\text { open. }\end{array}$ & $47.4 \%$ & $36.6 \%$ \\
\hline Children at an early age accept the given information without questioning. & $26.3 \%$ & $36.7 \%$ \\
\hline
\end{tabular}

In the light of the data above, it can be concluded that the teachers are aware of critical age hypothesis and they also know that children may learn a foreign language more easily. Parents think that children accept any information without questioning. It may be an advantage for teaching children. Because they acquire language unconsciously. Parents' answers are not compatible with the teachers' propositions. Parents do not agree with the teachers about advantages of early foreign language education.

Tablo 3. Views about the Disadvantages of Early Foreign Language Education

\begin{tabular}{lcc}
\hline & Teachers & Parents \\
\hline It may inhibit mother tongue development which has been newly acquired. & $28 \%$ & $25 \%$ \\
\hline It may slow down children's own cultural development. & $0 \%$ & $33.4 \%$ \\
\hline It may be difficult for children in terms of cognitive development. & $14.3 \%$ & $12.5 \%$ \\
\hline $\begin{array}{l}\text { If appropriate environments are not provided, children might gain prejudice } \\
\text { against foreign language and culture. }\end{array}$ & $44.5 \%$ & $29.2 \%$ \\
& \\
\hline
\end{tabular}

According to Table 3, although most of the teachers find early foreign language education beneficial, there are some teachers who state that there may be some disadvantages. These worries are mostly about the culture, mother tongue and cognitive development. As it is seen, both teachers and parents agree that development of Turkish language may be affected negatively while they are learning English. While the teachers never think that learning English may block children's Turkish cultural development and it is clearly evident that parents are worried about learning English may affect their cultural development in a negative way.

Tablo 4. Views about the Deficiencies of Early Foreign Language Education in Turkey

\begin{tabular}{lcc}
\hline & Teachers & Parents \\
\hline The new system about early foreign language does not work properly. & $52.9 \%$ & $36 \%$ \\
\hline $\begin{array}{l}\text { The program is not known well enough by the teachers and } \\
\text { administrators. }\end{array}$ & $17.6 \%$ & $8 \%$ \\
\hline The number of English teachers teaching to children at an early age take & $29.4 \%$ & $40 \%$ \\
\hline
\end{tabular}




\begin{tabular}{lcc}
\hline a special education in this field is not enough. & & \\
\hline $\begin{array}{l}\text { The schools and classes are lack of suitable materials and } \\
\text { technical equipment. }\end{array}$ & $70.6 \%$ & $44 \%$ \\
\hline The class is overcrowded. & $29.4 \%$ & $4 \%$ \\
\hline
\end{tabular}

As can be seen above, most of the teachers complaint about the physical environment and course materials. Early foreign language education requires attractive materials and suitable environment when the students ages taking into consideration. Besides, teachers state that the system has not been fully settled yet. As mentioned above, regulation change about early foreign language education is so new in Turkey. Thus, getting the views of the teachers about the new system may be useful for the prospective regulation changes. About the deficiencies in Turkey, parents' answers are closer to the teachers' answers. Both of them think that the first problem is to design physical environment for teaching English to children and to use effective course materials. It is very interesting that the parents think that teaching to children requires a special education but they indicate that the number of well-experienced teachers in that field is not so high.

Tablo 5. Views about the Harms of Early Foreign Language Education in terms of Their Mother Tongue and Turkish Culture

\begin{tabular}{lcc}
\hline & Teachers & Parents \\
\hline $\begin{array}{l}\text { When the child who could not comprehend his/her own culture completely } \\
\text { encounters the other culture, he/she may experience a mental chaos. }\end{array}$ & $25 \%$ & $30.8 \%$ \\
\hline $\begin{array}{l}\text { The newly learnt information about the new culture may detract the child from } \\
\text { his/her own culture. }\end{array}$ & $0 \%$ & $15.4 \%$ \\
\hline $\begin{array}{l}\text { The child may add the words and expressions of foreign language to his/her } \\
\text { speech in his/her mother tongue. }\end{array}$ & $75 \%$ & $23.1 \%$ \\
\hline A new language and culture may make the child a wannabe for others. & $0 \%$ & $30.7 \%$ \\
\hline
\end{tabular}

The teachers think that early foreign language education may harm the mother tongue and Turkish culture. They worry that especially it may affect the children's first language learning since they will learn two languages simultaneously. The children may transfer the words or expressions in English to Turkish. While teachers do not state that learning English and English culture detract children from Turkish culture, some of the parents think the opposite.

Tablo 6. English Language Teachers' Views about Course Materials Used in Early Foreign Language Education

\begin{tabular}{lc}
\hline & Percentage \\
\hline Course Book & $15 \%$ \\
\hline Blackboard & $35 \%$ \\
\hline Computer & $50 \%$ \\
\hline Projector & $50 \%$ \\
\hline 3 D Material & $75 \%$ \\
\hline TV & $45 \%$ \\
\hline Photocopy & $25 \%$ \\
\hline Slide & $30 \%$ \\
\hline Board & $40 \%$ \\
\hline Flash Cards & $80 \%$ \\
\hline
\end{tabular}

Course materials are very crucial especially for early foreign language education, because activating children's senses and attracting them require materials beyond the course books and the blackboard. Therefore, as the teachers indicate, materials such as flash cards, 3D materials, computer, projector etc. are useful and effective materials for early foreign language classes. 
Tablo 7. English Language Teachers' Views about the Activities That Should Be Used More in Early Foreign Language Classes

\begin{tabular}{lc}
\hline Activities & Percentage \\
\hline Speaking activities & $85 \%$ \\
\hline Listening activities & $45 \%$ \\
\hline Drama activities & $65 \%$ \\
\hline Games & $55 \%$ \\
\hline Telling stories & $35 \%$ \\
\hline Singing songs & $65 \%$ \\
\hline Crossword & $30 \%$ \\
\hline
\end{tabular}

Mostly chosen activity by the teachers is speaking activities. Drama and listening, and singing songs follow it. However, the percentages of listening activities, games, storytelling and puzzles are lower than expected, because they are also important recommended activities for early foreign language learning. The methods used for children require games, drama and interactive activities. Especially, games are children's routines at these ages.

Tablo 8. English Language Teachers' Views about the Number of Students in Early Foreign Language Classes

\begin{tabular}{lc}
\hline Number of Students & Percentage \\
\hline $10-15$ & 75 \\
\hline $16-20$ & 25 \\
\hline $21-25$ & 0 \\
\hline $26-30$ & 0 \\
\hline $31-35$ & 0 \\
\hline
\end{tabular}

The number of the students is an important factor for EFL classes. Little children need much more attention and interest, because they are more active physically. The table 8 above also shows that optimal number of the students in EFL classes should be 10-15 at most. Therefore, the number of the students should be decreased in the classes including more than 10-15 students in Turkey. Over-crowded class is big problem in terms of classroom management in ELT. It is difficult to plan and design to do necessary activities which appeal to students needs and expectations in the crowded classroom. In addition, Time management is another problem for this type of classroom.

Tablo 9. English Language Teachers' Views about the Frequency of the Use of the Target Language and Mother Tongue in the Class

\begin{tabular}{cccccc}
\hline & Always & Often & Sometimes & Occasionaly & Never \\
\hline $\begin{array}{c}\text { Mother } \\
\text { Tongue }\end{array}$ & 10 & 10 & 30 & 50 & 0 \\
\hline $\begin{array}{c}\text { Target } \\
\text { Language }\end{array}$ & 40 & 50 & 10 & 0 & 0 \\
\hline
\end{tabular}

Teachers views about the use of target language and mother tongue as follows: $50 \%$ of the teachers claim that the target language should be frequently used. In addition, $40 \%$ of them state that it should be used always. With regard to mother tongue, $50 \%$ of them state it should be used rarely, and 30\% of them stated it should be used sometimes. It is a contradictory statement for foreign language education that some teachers claim that mother tongue should always be used in EFL classes.

Tablo 10. Parents' Views about to which Sides of the Students Early Foreign Language Education Contributes Most

\begin{tabular}{cc}
\hline & Percentage \\
\hline It supports children's social development & $46.7 \%$ \\
\hline
\end{tabular}




\begin{tabular}{l}
\hline It enables that children's mental development will be faster. \\
\hline $\begin{array}{l}\text { It enables children to be aware of themselves and their } 10 \% \\
\text { qualifications psychologically }\end{array}$
\end{tabular}

According to the table 10, most of the parents think that early foreign language education will support children's both social and mental development. Learning a foreign language help them to know themselves. As they are actively participated activities in the class, they help each other and they have chance to know both their friends and themselves.

Tablo 11. Parents' Views about whether English Language is a Distinctive Feature for the Future of the Children

\begin{tabular}{lc}
\hline & Percentage \\
\hline English is enough & $13.3 \%$ \\
\hline They should learn another foreign language alongside English & $26.7 \%$ \\
\hline It can be beneficial for them to learn another foreign language alongside English. & $60 \%$ \\
\hline
\end{tabular}

While $13.3 \%$ of the parents think that English is a distinctive feature for the future of the children, 26.7 of them think another foreign language should be learnt, and $60 \%$ of them state another language can be beneficial for them.

\section{Conclusion}

It can be concluded that teachers and parents are in favor of early foreign language education, especially at between the ages 4-7. Most of the teachers and parents agree that early foreign language education should start at preschool. It shows that the recent regulation change, which states English courses will be started at the 2nd grade of the primary schools, is a positive and valuable attempt for early foreign language education in Turkey which is in the way of being a member of European Union.

Both the teachers and parents think that children may experience a mental shock if they do not attain cultural awareness in their own culture. Besides, they agree that learning a foreign language may inhibit mother tongue development. The teachers think that early foreign language education has some advantages in terms of children's cognitive and psychological development, socialization, awareness and so on. In other words, the teachers are aware of critical age hypothesis. However, some of the parents are not conscious enough about foreign language learning. In addition, both the teachers and the parents complain about the number of the students and the deficiencies at the present system. Both of teachers and parents think that the first problem in teaching English to children is to design appropriate physical environment and to use effective course materials.

Besides, teachers claim that the target language should be frequently used.in foreign language class. They indicate that materials such as flash cards, 3D materials, computer, projector etc. are useful and effective materials for early foreign language classes. The teachers frequently use speaking activities in EFL classroom. Both the teachers and the parents indicate that the number of the students in the class should be 10-15 at most. Also, the parents think that children should learn another foreign language alongside English.

\section{Suggestions}

This study has investigated the English language teachers and the parents of primary school students about early foreign language education. According to the results, the following suggestions should be made: The deficiencies in the present system should be 
revised. The number of the students in the early foreign language classes should be decreased at an optimal number for an effective teaching and learning. English language teachers should take special trainings appealing to the needs of the children. In addition, teachers and parents should be informed about the early foreign language education more detailed. Foreign language classroom should be designed, attractive and various course materials should be selected appropriately for the students at these ages. The starting age for early foreign language education can be decreased at preschool period for all of the children in Turkey according to the results about the starting age (between 4-7 years old).

A further study can be conducted with a larger number of participants. Besides, another research can investigate the views of parents in the countryside and in the urban. Last but not the least, parents' and English language teachers' views about early foreign language education can be compared with students' achievement in English language.

\section{REFERENCES}

Aküzel, G. (2006). İlköğretim 4-8. Sinıflarda yabancı dil öğretimindeki başarısızlık nedenlerinin incelenmesi (Adana Örneği) (Unpublished master's thesis). Çukurova Üniversitesi Sosyal Bilimler Enstitüsü. Adana.

Aslan, N. (2008). Dünyada erken yaşta yabancı dil öğretimi uygulamaları ve Türkiye'deki durum. Çukurova Üniversitesi Ĕ̈itim Fakültesi Dergisi, 35 (3), 1-9.

Atadere, K.Y. (2012). Türkiye'de erken yaşta yabancı dil ĕgitimi. Veli ve ögretmenlerin erken yaşta yabancı dile yönelik algı ve tutumları (Master's thesis). Muğla Üniversitesi Eğitim Bilimleri Enstitüsü, Muğla.

Birdsong, D. (1999). Second language acquisition and the critical period hypothesis. London: Lawrence Erlbaum Associates, Inc.

Demirezen, M. (2003). Yabancı dil ve anadil öğreniminde kritik dönemler. Dil Dergisi. 118, 5-15.

Eurydice (Education, Audiovisual and Culture Executive Agency) (2012). Avrupa'da okullarda dil öğretimi hakkında temel veriler. Retrieved in May 2015 from http://eacea.ec.europa.eu/education/eurydice/documents/key_data_series/095TR.pdf

Genç, İ. B. and Er, S. (2007). Erken yaşta yabanc1 dil öğretimi üzerine veli ve öğretmen görüşleri. Kastamonu Eğitim Dergisi. 15, 1, 21-30.

Gül, P. (2009). Critical period hypothesis for second language acquisition: A review of the literature. Retrieved in June from https://www.academia.edu/290567/Critical_Period_Hypothesis_for_Second_Languag e_Acquisition_A_Review_of the Literature

Johnson, J. S. and Newport, E. L. (1989). Critical period effects in second language learning: the influence of maturational state on the acquisition of English as a second language. Cognitive Psychology. 21, 60-99.

Küçüktepe, C., Eminoğlu Küçüktepe, S. and Baykın, Y. (2014). İkinci sınıf ingilizce dersi ve programına ilişkin öğretmen görüşlerinin incelenmesi. Hasan Ali Yücel Ĕgitim Fakültesi Dergisi. $22 \quad$ (11), 55-78. Retrieved from http://www.journals.istanbul.edu.tr/iuayefd/article/viewFile/5000070044/500008004 $\underline{2}$.

Marinova-Todd, S. H., Marshall, D. B., and Snow, C. E. (2000). Three misconceptions about age and L2 learning. TESOL Quarterly, 34, 9-34. Retrieved from http://www.utdallas.edu/ assmann/hcs6367/marinova_todd_marshall_snow00.pdf

Mauranen, A. and Ranta, E. (2009). English as a lingua franca: Studies and findings. UK: Cambridge Scholars Publishing. 
Milli Eğitim Bakanlığı (MEB) (2012). Talim ve Terbiye Kurulu Başkanlığı İlköğretim Kurumları (İlkokullar ve Ortaokullar) Haftalık Ders Çizelgesi. Retrieved from http://nigde.meb.gov.tr/meb_iys_dosyalar/2012_06/27112918_ttk_69_25062012.pdf. pdf

Scovel, T. (2000). A critical review of the critical period research. Annual Review of Applied Linguistics, 20, 213-223.

Takutome, M. (2010). Unlikely bedfellows: The critical period hypothesis and its effects on second language acquisition. TPFLE. 1 (14), 18-27. Retrieved from https://studentorgs.utexas.edu/flesa/TPFLE_New/Issues/Summer\%202010/3_Makot o\%20Tokudome.pdf

Yıldıran, Ç. and Tanrıseven, I. (2015). İngilizce öğretmenlerinin ilkokul 2. sınıf ingilizce dersi öğretim programı hakkındaki görüşleri. International Journal of Language Academy. 3 (1), 210-223. 